Leonie Pawlita

Staging Doubt 



\section{Leonie Pawlita}

Staging Doubt

Skepticism in Early Modern European Drama

\section{DE GRUYTER}


This book is published in cooperation with the project DramaNet, funded by the European Research Council

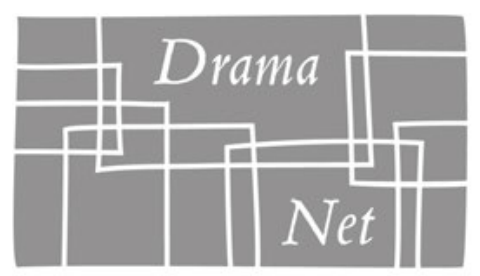

Early Modern European Drama and the Cultural Net

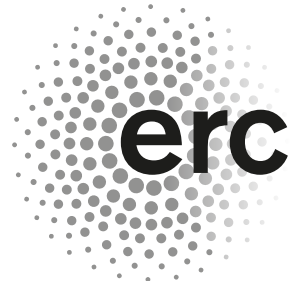

European Research Council

Established by the European Commission

ISBN 978-3-11-066055-5

e-ISBN (PDF) 978-3-11-066058-6

e-ISBN (EPUB) 978-3-11-066054-8

\section{(cc) BY-NC-ND}

This work is licensed under a Creative Commons Attribution-NonCommercial-NoDerivatives 4.0 International License. For details go to http://creativecommons.org/licenses/by-nc-nd/4.0/.

\section{Library of Congress Control Number: 2019945619}

Bibliographic information published by the Deutsche Nationalbibliothek The Deutsche Nationalbibliothek lists this publication in the Deutsche Nationalbibliografie; detailed bibliographic data are available on the Internet at http://dnb.dnb.de

(C) 2019 Leonie Pawlita, published by Walter de Gruyter GmbH, Berlin/Boston The book is published with open access at www.degruyter.com.

Typesetting: Integra Software Services Pvt. Ltd.

Printing and binding: CPI books $\mathrm{GmbH}$, Leck

Cover illustration: photodeedooo/iStock/Thinkstock

www.degruyter.com 
In memory of my father 
